\title{
THE IMPORTANCE OF AGRICULTURE IN THE DEVELOPMENT OF ROMANIAN ECONOMY
}

\author{
Miroslav Raicov, Vasile Goșa, Adina Fuchs \\ Banat's University of Agricultural Sciences and Veterinary Medicine "King Michael I of \\ Romania” from Timisoara, Faculty of Farm Management \\ 119 Calea Aradului Street, 300645 Timisoara, Romania \\ mikiraicov@gmail.com
}

\begin{abstract}
Agriculture represent one of the most important branches of the Romanian economy. Within performing the suggested analysis we started from the premise that the economy of each country, regardless of developing degree, agriculture, by natural and human resources available, by contributing to the creation of gross domestic product, of gross value added, but also by participating at internal and external trade, obviously holds an important position.

Romanian rural economy is currently dominated in a large part by agriculture. Favorable geographical conditions, topography, climate, fertile soils, in addition with workforce, a suitable administrative system, but the connection of rural population to land and animals can make the Romanian agriculture as production branch attractive and profitable to determine economic growth at national level.

Thus, we considered necessary to perform an analysis concerning the importance of Romanian agriculture, analysis that represents the basis for finding the most viable solutions to determine this particularly important branch - to relaunch in the development of Romanian rural economy.
\end{abstract}

Keywords: agriculture, rural development, economic growth

\section{INTRODUCTION}

Every country has a specific economic structure determined by its level of development, historical evolution and by its specific policy of regulating social life (FEHER ET AL., 2012). The privatization process in Romania started in 1990, proved to be a much more complex and more difficult than was originally thought. In the first period after 1990 the process was slowly being determined by: the lack of political will, mentality and indoctrination of population, by institutional problems, as well by a slow establishing of a necessary legal framework.

Within agriculture, the evolution was much faster and with great leaps even since the early years of transition. Otherwise the privatization process started in agriculture within the cooperative sector in the spring of 1990.

Romanian agriculture has evolved in the period after 1990 under the influence of phenomena generated by the transition towards a market economy, on the background of shortage of financial resources and material, as well of an unfavorable international recession (STERIU, OTIMAN ET AL., 2013).

Land Law 18/1991 divided agricultural lands into small parcels and determined their dispersion, to which was added the depreciation of the material basis, the stagnation of investments, asset damage, as well as mistakes occurred in the management of state-owned assets and supporting the process of establishing private agriculture, which led to the sharp decline of farms profitability.

Currently, Romania continues to be known as "the most rural country in Europe" (NIS Social TRENDS, 2016).

Statistics show that nearly half of the country population is represented by the rural population, meaning 9,71 million people $(46 \%)$. 
The majority of rural inhabitants are employed in agriculture, forestry and fisheries $(41.3 \%)$ while only $32.6 \%$ work in the secondary sector and $26.1 \%$ in the tertiary sector. Most of those working in agriculture are their own employees and the number of employees in agriculture represents only $5.45 \%$ of total number of employees in the economy.

\section{MATERIAL AND METHOD}

The methods used at elaboration of the present work are: analysis, synthesis, comparison, deduction or induction. The data used were taken from statistics of European Commission, Eurostat and national statistics, also from various national and international publications, on which we made own calculations and interpretations. The indicators used in this analysis are the followings:

1. Gross domestic product which is equivalent to the amount of gross value added of various institutional sectors or of various branches of activity, to which is added taxes and are deducted subsidies on products (which are not allocated to sectors and activity branch). In the same time it represents the production balance of the total economy. The value of gross domestic product is expressed in current and comparable prices.

2. Gross value added which represents the balance of production, meaning the new created value in the production process.

3. Net investments represent expenditures made for construction works, installation and assembly, equipment purchase, transportation and other expenses intended for the creation of new fixed assets, for development, modernization, reconstruction of the existing ones, as well as the value of services related to ownership transfer of existing fixed assets and lands (notary fees, commissions, costs of transport, loading and unloading, etc.).

4. International trade includes all operations of import and export regarding goods, works and services carried out by individuals or entities having the quality of subjects of international trade right with partners of foreign nationality or with goods at international transit.

5. Trade balance represents the net difference between the value of imports and exports of goods within a country in a given period of time.

\section{RESULTS AND DISCUSSION}

Across the entire national economy, agriculture represents one of the branches of major importance, which can contribute to the revival of economic growth of the country, especially since the role that agriculture has, it cannot be substituted by any other economic activity due to the fact that food demand is essential and has a permanent character for human existence on the one hand, and on the other hand agriculture provides raw material needed for the revival of many other industries (agro-food, textile, chemical, pharmaceutical, cosmetics, handicrafts etc).

The contribution of agriculture to economic development can be determined by performing an analysis of the multiple functions which are accomplished by this, as well by its contribution at the balance and social stability and not only, in the light of the share of this branch in the formation of outcome indicators such as gross domestic product and added value (GoşA ET AL., 2013).

Through agriculture, every nation must ensure food security of the population, meaning the possibility for all citizens to have permanently a sufficient amount of food to lead an active and healthy life. 
Nationally, agriculture is one of the main branches of the Romanian economy with a relatively high share in gross domestic product (Table 1).

Table 1. The share of agriculture and forestry to GDP (million euro)

\begin{tabular}{|l|r|r|r|r|r|r|r|r|r|}
\hline Indicator/Year & \multicolumn{1}{|c|}{$\mathbf{2 0 0 1}$} & \multicolumn{1}{|c|}{$\mathbf{2 0 0 3}$} & \multicolumn{1}{|c|}{$\mathbf{2 0 0 5}$} & \multicolumn{1}{c|}{$\mathbf{2 0 0 7}$} & \multicolumn{1}{c|}{$\mathbf{2 0 0 9}$} & \multicolumn{1}{c|}{$\mathbf{2 0 1 1}$} & \multicolumn{1}{c|}{$\mathbf{2 0 1 3}$} & \multicolumn{1}{|c|}{$\mathbf{2 0 1 4}$} & \multicolumn{1}{|c|}{$\mathbf{2 0 1 5}^{*}$} \\
\hline Total GDP & 44866 & 52607 & 79532 & 124653 & 120483 & 133344 & 144253 & 149988 & 159790 \\
\hline $\begin{array}{l}\text { GDP } \\
\text { agriculture } \\
\text { and forestry }\end{array}$ & 5999 & 6080 & 6700 & 7181 & 6555 & 8580 & 7785 & 7106 & 6698 \\
\hline \% of GDP & 13.4 & 11.6 & 8.4 & 5.8 & 5.4 & 6.4 & 5.4 & 4.7 & 4.2 \\
\hline
\end{tabular}

Source: National Institute of Statistics, Tempo Online database;

* National Institute of Statistics, Press Release, Nr. 54 of March $8^{\text {th }}, 2016$

The contribution of agriculture and forestry to GDP in the year 2001 had a share of about $13.4 \%$, and in the year 2015 approx. $4.2 \%$. Although the contribution of agriculture to GDP has declined pretty much the period under review, it continues to hold a high share compared to developed countries, EU countries, where agriculture's contribution to GDP does not exceed $2 \%$ (Table 2).

Table 2. Structure of Gross Value Added (GVA) in the EU 2014

\begin{tabular}{|l|c|c|c|c|c|}
\hline Country & Agriculture & Industry & Constructions & $\begin{array}{c}\text { Trade, Transport, } \\
\text { Accommodation } \\
\text { and Food }\end{array}$ & Others \\
\hline Austria & 1.54 & 21.74 & 6.90 & 21.89 & 47.94 \\
\hline Belgium & 0.79 & 15.56 & 5.75 & 19.79 & 58.12 \\
\hline Bulgaria & 4.95 & 25.19 & 5.60 & 19.50 & 44.77 \\
\hline Czech & 2.39 & 31.81 & 5.95 & 19.19 & 40.66 \\
\hline Cyprus & 2.67 & 8.74 & 4.05 & 24.32 & 60.22 \\
\hline Croatia & 4.41 & 21.01 & 5.28 & 20.66 & 48.64 \\
\hline Denmark & 1.31 & 16.88 & 4.60 & 19.70 & 57.51 \\
\hline Estonia & 3.61 & 21.46 & 7.61 & 23.19 & 44.12 \\
\hline Finland & 2.84 & 18.73 & 6.84 & 17.00 & 54.59 \\
\hline France & 1.80 & 12.79 & 6.05 & 18.18 & 61.18 \\
\hline Germany & 0.78 & 25.53 & 4.68 & 14.48 & 54.54 \\
\hline Greece & 3.71 & 14.64 & 1.82 & 22.71 & 57.12 \\
\hline Ireland & 1.85 & 26.34 & 1.68 & 15.58 & 54.55 \\
\hline Italy & 2.15 & 18.29 & 5.61 & 20.83 & 53.12 \\
\hline Latvia & 4.89 & 18.69 & 6.39 & 29.14 & 40.89 \\
\hline Lithuania & 3.84 & 24.54 & 6.54 & 33.20 & 31.87 \\
\hline Luxemburg & 0.34 & 5.88 & 6.25 & 17.62 & 69.91 \\
\hline Malta & 1.66 & 12.83 & 4.10 & 21.02 & 60.39 \\
\hline Great Britain & 0.64 & 14.33 & 6.06 & 18.46 & 60.51 \\
\hline Netherlands & 1.65 & 19.65 & 4.72 & 18.61 & 55.37 \\
\hline Poland & 3.79 & 24.73 & 6.54 & 27.28 & 37.66 \\
\hline Portugal & 2.41 & 18.90 & 4.29 & 25.37 & 49.04 \\
\hline Romania & $\mathbf{6 . 3 8}$ & $\mathbf{3 4 . 2 6}$ & $\mathbf{9 . 1 9}$ & $\mathbf{1 2 . 5 1}$ & $\mathbf{3 7 . 6 6}$ \\
\hline Slovakia & 2.95 & 26.65 & 7.56 & 22.82 & 40.01 \\
\hline Slovenia & 2.90 & 25.72 & 5.67 & 20.61 & 45.10 \\
\hline Spain & 2.58 & 17.46 & 7.84 & 25.90 & 46.21 \\
\hline Sweden & 1.51 & 18.81 & 5.38 & 17.51 & 56.78 \\
\hline Hungary & 4.80 & 26.03 & 4.11 & 17.57 & 47.48 \\
\hline Total EU 28 & 1.68 & 19.06 & 5.67 & 18.98 & 54.61 \\
\hline Sour & & & & \\
\hline
\end{tabular}

Source: Own calculations based on Eurostat online database 
In developed countries, agriculture participates with a share more than the gross value added (GVA), which warranted the development at a sustained pace of other sectors such as services, trade, construction, financial, banking, insurance, whose participation is growing to achieve gross value added.

In Romania agriculture's contribution to GVA in the year 2014 was of $6.38 \%$ while the EU average is $1.68 \%$. The large share of Romanian agriculture compared to other EU countries to GVA formation at economy level is due to the too slow growth process of the share of services and trade to total gross value added.

In what concerns the Romanian agriculture investments in the period under review, these accounted on average for $4.12 \%$ of the total allocated investments according to the table below (Table 3).

Table 3. The evolution of investments structure in Romania, $\%$

\begin{tabular}{|c|c|c|c|c|c|c|c|c|c|c|c|c|c|c|}
\hline \multirow[t]{2}{*}{ Specification } & \multicolumn{2}{|c|}{2008} & \multicolumn{2}{|c|}{2009} & \multicolumn{2}{|c|}{2010} & \multicolumn{2}{|c|}{2011} & \multicolumn{2}{|c|}{2012} & \multicolumn{2}{|c|}{2013} & \multicolumn{2}{|c|}{2014} \\
\hline & Mil. $€$ & $\%$ & Mil. $\epsilon$ & $\%$ & Mil. $€$ & $\%$ & Mil. E & $\%$ & Mil. € & $\%$ & Mil. $€$ & $\%$ & Mil. $€$ & $\%$ \\
\hline Agriculture & 921 & 3.41 & 689 & 3.90 & 632 & 3.68 & 775 & 3.74 & 757 & 3.78 & 963 & 5.27 & 988 & 5.10 \\
\hline Indust & 8709 & 32.22 & 6060 & 34.27 & 6458 & 37.61 & 7813 & 37.71 & 7971 & 39.87 & 7845 & 42.88 & 7890 & 40.70 \\
\hline Constructions & 3676 & 13.61 & 2166 & 12.24 & 2192 & 12.76 & 2985 & 14.40 & 2929 & 14.65 & 1995 & 10.90 & 1434 & 7.40 \\
\hline Trade & 3911 & 14.47 & 2118 & 11.98 & 1625 & 9.46 & 1980 & 9.55 & 1937 & 9.69 & 1727 & 9.44 & 1826 & 9.41 \\
\hline Others & 9808 & 36.29 & 6653 & 37.61 & 6266 & 36.49 & 7170 & 34.60 & 6400 & 32.01 & 5766 & 31.51 & 7247 & 37.39 \\
\hline Total & 27025 & 100 & 17686 & 100 & 17173 & 100 & 20722 & 100 & 19994 & 100 & 18296 & 100 & 19385 & 100 \\
\hline
\end{tabular}

Source: Processed data from the National Institute of Statistics, Tempo Online database

In these circumstances we can not talk about investments for development, but mostly only capital allocation for replacement of fixed assets.

In the year 2014, crop production represented 65.83\%, while livestock production accounted for only $32.85 \%$ of total agricultural production (Table 4 ).

Table 4. The evolution of sectors shares in agriculture

\begin{tabular}{|c|c|c|c|c|c|c|c|c|}
\hline \multirow[t]{2}{*}{ Specification } & \multicolumn{2}{|l|}{2011} & \multicolumn{2}{|l|}{2012} & \multicolumn{2}{|l|}{2013} & \multicolumn{2}{|l|}{2014} \\
\hline & $\begin{array}{l}\text { mil. } € \text { current } \\
\text { prices }\end{array}$ & $\%$ & $\begin{array}{c}\text { mil. } € \text { current } \\
\text { prices }\end{array}$ & $\%$ & $\begin{array}{c}\text { mil. } € \text { current } \\
\text { prices }\end{array}$ & $\%$ & $\begin{array}{c}\text { mil. } € \text { current } \\
\text { prices }\end{array}$ & $\%$ \\
\hline Vegetal & 12784.58 & 70.82 & 9014.62 & 62.51 & 12184.61 & 68.62 & 11037.74 & 65.83 \\
\hline Livestock & 5140.31 & 28.47 & 5286.19 & 36.66 & 5403.15 & 30.43 & 5508.17 & 32.85 \\
\hline $\begin{array}{l}\text { Agricultural } \\
\text { services }\end{array}$ & 128.55 & 0.71 & 120.08 & 0.83 & 168.37 & 0.95 & 221.50 & 1.32 \\
\hline TOTAL & 18053.44 & 100 & 14420.89 & 100 & 17756.13 & 100 & 16767.41 & 100 \\
\hline
\end{tabular}

Source: Processed data from the National Institute of Statistics, Tempo Online database;

According to data from the above table, we find also that the share of livestock sector is low, although it discusses continuously of a share increase of this sector. Unfortunately, livestock have fallen sharply in the past 25 years mainly due to lack of animal slaughter establishments and of establishments for processing products from the livestock sector.

Low competitiveness of the obtained products is the main problem of the Romanian agriculture and the agricultural products can hardly find marketing on international market. The main exported products of Romania were wheat and corn with over 1.988 million euro in 2014. Romania thus is exporting large quantities of cereals to the detriment of their 
internal recovery through livestock, which could lead at increasing the added value of such products (Table 5).

Table 5. International trade with agricultural products

\begin{tabular}{|c|c|c|c|c|c|c|c|c|c|c|c|c|c|c|c|}
\hline \multirow{2}{*}{$\mathrm{NC}$} & \multirow[b]{2}{*}{ Specificat. } & \multicolumn{7}{|c|}{ EXPORT } & \multicolumn{7}{|c|}{ IMPORT } \\
\hline & & 2008 & 2009 & 2010 & 2011 & 2012 & 2013 & 2014 & 2008 & 2009 & 2010 & 2011 & 2012 & 2013 & 2014 \\
\hline I & $\begin{array}{c}\text { Live } \\
\text { animals } \\
\text { and } \\
\text { animal } \\
\text { products }\end{array}$ & 278 & 326 & 434 & 584 & 731 & 745 & 744 & 1191 & 1116 & 984 & 965 & 1035 & 1114 & 1223 \\
\hline II & $\begin{array}{c}\text { Crop } \\
\text { products } \\
\text { i.e. }\end{array}$ & 1198 & 1125 & 1625 & 2097 & 1970 & 2985 & 3068 & 1259 & 1003 & 1141 & 1324 & 1416 & 1455 & 1514 \\
\hline & Cereals & 638 & 631 & 893 & 1095 & 1336 & 1981 & 1988 & 308 & 250 & 248 & 333 & 373 & 327 & 256 \\
\hline III & $\begin{array}{c}\text { Animal } \\
\text { and crop } \\
\text { fats and } \\
\text { oils }\end{array}$ & 106 & 88 & 164 & 242 & 183 & 240 & 212 & 227 & 160 & 217 & 245 & 239 & 205 & 164 \\
\hline IV & $\begin{array}{c}\text { Food, } \\
\text { beverages } \\
\text { and } \\
\text { tobacco }\end{array}$ & 583 & 704 & 890 & 1099 & 1160 & 1315 & 1549 & 1669 & 1544 & 1584 & 1911 & 2100 & 2177 & 2219 \\
\hline To & & 2165 & 2243 & 3113 & 4022 & 4044 & 5285 & 5573 & 4346 & 3823 & 3926 & 4445 & 4790 & 4951 & 5120 \\
\hline
\end{tabular}

Source: Minister of Agriculture and Rural Development;

Table 6. The trade balance (export-import)

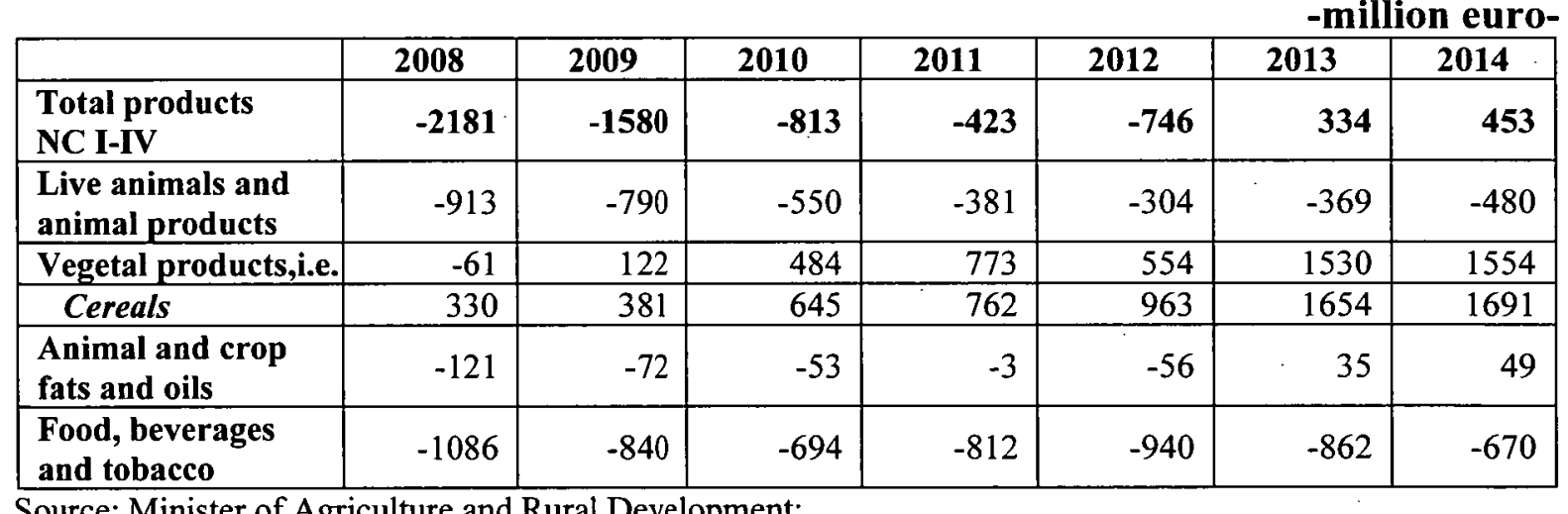

Source: Minister of Agriculture and Rural Development;

The trade balance of agricultural products in the last 2 years is overall positive. For vegetal products, the balance is positive since the year 2009. The most favorable situation is seen in the case of cereals, where the difference between exports and imports has increased constantly. At live animals and animal products there have recorded a downward trend in the deficit (Table 6).

The first year with overall positive balance was the year 2013 (334 million euros), mainly due to crop products, to which exports exceeded imports by 1530 million euros.

At food, beverages and tobacco, the deficit was maintained around the average value on 7 years of about 840 million euros.

Department stores (supermarkets, hypermarkets) prefer to sell imported products to which they have a faster access, while Romanian agricultural products still hardly find the route to the final consumer.

From this very important point of view results that local producers must associate in order to capitalize production, especially since the competition from EU countries remains high. 


\section{CONCLUSIONS}

In the situation where Romania's agriculture is characterized by a high degree of fragmentation of farmlands, low investments, poorly qualified workforce, aging and with a precarious financial situation, that lives mostly at subsistence limit, we believe that the revival of this branch so important for our country's economy can only be achieved by attracting European funds and through massive investments (FEHER ET AL., 2015).

Romanian producers should act in accordance with the existing economic realty nationally and globally and to apply technical and economic methods in order to provide them stability and economic efficiency;

Agricultural products capitalization is not well organized, the route from farmer producer to final consumer meets syncope which lead to losses for both producers and consumers; In the year 2014, the trade balance was positive by 453 mil. Euro. Exports, respectivelly imports of agricultural products represented $10.6 \%$ of total value of exports FOB, accounting for $8.7 \%$ of the total value of imports CIF.

Romanian agriculture benefited during the period 2007-2013 from European funds under the National Rural Development Programme worth around 8.124 million euros to which is added 2,000 million euros from domestic budgetary resources. In this period there were attracted approximately 8.457 million euros, meaning an absorption degree of $90.97 \%$.

For the period 2014-2020, there have been allocated to Romania European funds amounting to 8.015 million euros to develop the agricultural sector. These amounts should be targeted in particular to develop the livestock sector, and the food industry to stop exporting cereals and thereby to increase the value of these products.

We strongly advocate that agriculture must become a real priority for the Romanian government for it must ensure food security for the population but at the same time it must provide raw material for many other activities.

\section{ACKNOWLEDGEMENTS}

This work was supported by a grant of the Romanian National Authority for Scientific Research and Innovation, CNCS - UEFISCDI, project number PN-II-RU-TE-2014-4-1134.

\section{REFERENCES}

Feher, A., Goşa, V., Stanciu, S.M., Raicov, M., Pentea, O.A. (2012): Rural development financing. The new E.U. Multiannual Financial Framework 2014-2020, Lucrări ştiinţifice Management Agricol, Seria I, vol. XIV(3), ISSN: 1453-1410

FEHER, A., Goß̦A, V., HuRMUZACHE, T., RAICOV, M., (2015): Investment valences of the fund for rural development on the Romanian rural economy, Abstracts / Journal of Biotechnology 208 (2015) S5-S120, p. 54

Goß̧a, V., Feher, A., Raicov, M., Goşa, C., (2013): Considerations concerning the European fiscal pact, Lucrări ştiinţifice Management Agricol, Timişoara, Seria I, vol. XV(3), ISSN: 1453-1410

Steriu, V., Otiman, P.I. (COORD.) (2013): Cadrul naţional strategic pentru dezvoltarea durabilă a sectorului agroalimentar şi a spaţiului rural în perioada 2014-2020-2030, Editura Academiei Române, Bucureşti

EUROSTAT (2016): online database

NATIONAL InSTITUTE OF STATISTICS, (2016): Tempo Online database;

NATIONAL InSTITUTE Of STATISTICS, (2016): Press Release, Nr. 54 of March $8^{\text {th }}, 2016$

Minister of Agriculture AND RURAl DEVElOPMENT, Romanian agriculture, accesed at http://www.madr.ro/docs/agricultura/agricultura-romaniei-2015.pdf 